University of Montana

ScholarWorks at University of Montana

3-1987

\title{
Heterozygosity and Oxygen-Consumption Rate as Predictors of Growth and Developmental Rate in Rainbow-Trout
}

Roy G. Danzmann

Moira M. Ferguson

Fred W. Allendorf

University of Montana - Missoula, Fred.Allendorf@umontana.edu

Follow this and additional works at: https://scholarworks.umt.edu/biosci_pubs

Part of the Biology Commons

Let us know how access to this document benefits you.

\section{Recommended Citation}

Danzmann, Roy G.; Ferguson, Moira M.; and Allendorf, Fred W., "Heterozygosity and Oxygen-Consumption Rate as Predictors of Growth and Developmental Rate in Rainbow-Trout" (1987). Biological Sciences Faculty Publications. 300.

https://scholarworks.umt.edu/biosci_pubs/300

This Article is brought to you for free and open access by the Biological Sciences at ScholarWorks at University of Montana. It has been accepted for inclusion in Biological Sciences Faculty Publications by an authorized administrator of ScholarWorks at University of Montana. For more information, please contact scholarworks@mso.umt.edu. 


\title{
HETEROZYGOSITY AND OXYGEN-CONSUMPTION RATE AS PREDICTORS OF GROWTH AND DEVELOPMENTAL RATE IN RAINBOW TROUT ${ }^{1}$
}

\author{
ROY G. DANZMANN, ${ }^{2}$ MOIRA M. FERGUSON, ${ }^{3}$ AND FRED W. ALLENDORF \\ Department of Zoology, University of Montana, Missoula, Montana 59812 \\ (Accepted 8/13/86)
}

\begin{abstract}
A significant positive association between body length and multiple-locus heterozygosity is reported in a strain of rainbow trout (Salmo gairdneri). There is also a significant negative association between the number of heterozygous loci per fish and oxygen-consumption rate. Although more heterozygous fish use less oxygen, the amount of variation explained by this relationship is small. No significant association between oxygen consumption and hatching time is evident, although fish in genotypic classes that had faster average developmental rates tended to use less oxygen. These results suggest that faster developmental and growth rates may be attributed partially to the greater metabolic efficiency of more heterozygous fish.
\end{abstract}

\section{INTRODUCTION}

Several recent studies have suggested that more heterozygous individuals have enhanced growth rates compared to more homozygous individuals. The positive relationship between heterozygosity and size has been detected in natural populations with individuals of approximately the same age (Singh and Zouros 1978; Zouros, Singh, and Miles 1980; Singh 1982; Koehn and Gaffney 1984) and different ages (Fujio 1982; Manwell and Baker 1982; King 1985). However, other studies have not detected such a relationship and sometimes have found that homozygotes may be larger than heterozygotes (Beaumont, Beveridge, and Budd 1983; Diehl et al. 1985b).

The observation that heterozygotes have enhanced growth rates prompted Koehn and Shumway (1982) to propose that heterozygotes are metabolically more efficient

\footnotetext{
${ }^{1}$ We thank Tom Pruitt of the Creston National Fish Hatchery for providing the rainbow trout gametes and Dr. Delbert Kilgore for technical advice and helpful suggestions on the manuscript. We also thank the reviewers of this manuscript for comments and suggestions. This research was supported by National Science Foundation grant BSR-8300039 awarded to F.W.A. M.M.F. was supported by a postgraduate scholarship from the Natural Sciences and Engineering Research Council of Canada.

${ }^{2}$ Present address: Chesapeake Bay Institute, The Johns Hopkins University, Shady Side, Maryland 20764.

${ }^{3}$ Present address: Department of Zoology, University of Guelph, Guelph, Ontario, Canada N1G 2W1.
}

Physiol. Zool. 60(2):211-220 1987.

(C) 1987 by The University of Chicago. All

rights reserved. $0031-935 \mathrm{X} / 87 / 6002-5123 \$ 02.00$ than homozygotes. The increased metabolic efficiency of heterozygotes was postulated to enhance growth rates because more energy would be available for growth because of lower routine metabolic costs. Koehn and Shumway (1982) observed that weight-specific oxygen-consumption rates were significantly lower in more heterozygous oysters (Crassostrea virginica) in both normal and stressful environments. A similar relationship has been detected in the coot clam Mulinia lateralis (Garton, Koehn, and Scott 1984) and tiger salamander Ambystoma tigrinum (Mitton, Carey, and Kocher 1986) under normal conditions. However, under stressed conditions (i.e., forced exercise) more heterozygous tiger salamanders used more oxygen than more homozygous animals (Mitton et al. 1986).

In contrast, Rodhouse and Gaffney (1984) did not find any differences in the mean adjusted oxygen-consumption rates of oysters with different levels of heterozygosity (high, medium, and low) but did find a difference in weight loss during starvation conditions. More heterozygous oysters lost weight at a slower rate than less heterozygous oysters, which suggests that the ability of heterozygotes to conserve energy under stress conditions accounted for their enhanced growth rates. Diehl, Gaffney, and Koehn (1985a) found a similar relationship with weight loss between homozygous and heterozygous mussels (Mytilus edulis) but also found that heterozygous mussels used less oxygen.

The rate of development in salmonid fishes is dependent on ambient oxygen 
conditions. Alderdice, Wickett, and Brett (1958) and Garside (1966) have shown that fish develop more slowly at lower oxygen tensions. Therefore, fish with lower metabolic requirements for oxygen should be able to maintain higher developmental rates in such environments. Even in environments where oxygen levels are not limiting, fish with lower metabolic requirements for oxygen should be able to assimilate more of their available energy into growth and development. If scope for growth and developmental rate are positively related, then fish with greater metabolic efficiency should hatch sooner. However, differences in the quantity and quality of energy reserves in the egg yolk (protein, lipid, and carbohydrate) may also influence developmental rates. Individuals with enhanced metabolic efficiencies may not necessarily develop faster if they have inferior energy reserves.

The present study examines the relationship among size, oxygen-consumption rate, and enzyme heterozygosity in rainbow trout (Salmo gairdneri). Our objective was to test whether more heterozygous fish are larger and have lower oxygen-consumption rates than more homozygous fish. We were also interested in determining the relationship between oxygen-consumption rate and developmental rate.

\section{MATERIAL AND METHODS}

EXPERIMENT 1

On January 13, 1984, gametes were removed from 25 males and 25 females of the Eagle Lake strain of rainbow trout maintained at the Creston National Fish Hatchery in Creston, Montana. A subsample of gametes from each individual were put into a separate container and transported to the University of Montana in Styrofoam coolers packed with ice. Approximately equal numbers of eggs from each female were combined and then mixed with equal volumes of sperm from the males to make a pooled cross. The embryos were incubated in darkness in a Heath incubating rack at $7.5 \pm 1 \mathrm{C}$ until yolk-sac resorption was almost complete. At this time the embryos were transferred to an aquarium with recirculating water and raised until they were 178 days old, postfertilization.
The Eagle Lake strain has been maintained at the Creston National Fish Hatchery since 1980 and originated from native resident fish of Eagle Lake, California. The strain has higher than average amounts of genetic variability compared with other wild and domestic strains of rainbow trout (Allendorf and Phelps 1981; Ferguson, Danzmann, and Allendorf 1985).

\section{EXPERIMENT 2}

On February 27, 1985, gametes were obtained from 10 males and 10 females of the Eagle Lake strain. A pooled cross as in experiment 1 was made, and the embryos were raised to hatching under conditions similar to those described for experiment 1. At hatching, embryos were separated into six temporal hatching groups. Each hatching group represented approximately onesixth of the total hatching distribution and corresponded to the sequential order of hatching for the pooled cross. The hatching groups were designated 1 through 6 , representing the first to last groups to hatch, respectively. After hatching was completed, the embryos of each hatching group were maintained in separate sections of a single Heath incubating tray until yolk-sac resorption was almost complete. At this time, all the hatching groups were transferred to separate but adjacent compartments in a recirculating aquarium and reared at $11 \pm 1$ C until the fish were 96 days old.

\section{HETEROZYGOSITY AND SIZE}

The relationships between average heterozygosity and length in experiment 1 and between average heterozygosity and wet weight of the fish in each hatching group in experiment 2 were examined using linear-regression procedures. For experiment 1 , differences between the lengths of fish homozygous and heterozygous at various enzyme loci were compared using a Wilcoxon two-sample test (Sokal and Rohlf 1981). Unless otherwise specified, the significance level in all statistical tests is .05 .

OXYGEN-CONSUMPTION RATE

Oxygen-consumption measurements were made using a Gilson differential respirometer (Gilson Medical Electronics). Each fish was placed in a $15-\mathrm{ml}$ respirometry flask and immersed in $3.5 \mathrm{ml}$ of aquar- 
ium water. Preliminary experiments with fish of the same age indicated that a shaking rate of $1503-\mathrm{cm}$ strokes per min was sufficient to overcome diffusion-limited transfer of gas into the volume of water used. Gas volumes were standardized (11 $\mathrm{C}, 1 \mathrm{~atm}$ ) and presented as microliters of oxygen consumed per hour. The final value used was obtained from a linear-regression equation calculated with standardized readings taken at 10-min intervals for $1 \mathrm{~h}$. Oxygen-consumption rates were calculated for 132 fish in experiment 2. Up to 14 fish were examined in the respirometer at the same time. Over a 3-day period, 10 experimental runs were conducted. The fish were starved for $24 \mathrm{~h}$ prior to observation. The oxygen-consumption rate $\left(\mathrm{VO}_{2}\right)$ per individual was standardized to that of a 300 $\mathrm{mg}$ wet-weight individual following the formula given by Koehn and Shumway (1982):

$$
\dot{\mathrm{VO}}_{2}=(300 \mathrm{mg} / W)^{b} \times \mathrm{VO}_{2(\text { exp })},
$$

where $W$ is the wet weight in milligrams of the experimental fish, $b$ is the slope from the regression of the log of oxygen consumption per hour on the log of the wet weight, and $\mathrm{VO}_{2(\exp )}$ is the oxygen consumption of the experimental fish. The calculated linear-regression equation for logtransformed oxygen consumption on wet weight was

$$
\log y=0.850 \log x-0.090 \text {. }
$$

The confidence interval for the slope of this equation is \pm 0.084 . There is no significant deviation from linearity for this regression (goodness-of-fit G-statistic $=0.30 ; 131 \mathrm{df}$ ) (Sokal and Rohlf 1981). Our calculated slope relating oxygen consumption and body weight is slightly higher than those reported previously for rainbow trout (Rao 1968) but falls within the $95 \%$ confidence intervals for these previous estimates. The relationship between average heterozygosity or hatching time and oxygen consumption per standardized 300-mg fish was examined using linear-regression procedures. Either a $t$-test or one-way ANOVA with the GT-2 method (for unequal sample sizes) of a posteriori means comparison (Sokal and Rohlf
1981) was used to test for differences in $\dot{\mathrm{V}}_{2}$ between genotypic classes at individual loci.

\section{ELECTROPHORESIS}

Enzymes produced by the following polymorphic loci were examined in each fish: glycerol-3-phosphate dehydrogenase (G3p1; EC 1.1.1.8), glycyl-leucine peptidase (Gll; EC 3.4.1.1), isocitrate dehydrogenase (Idh2 and Idh3,4; EC 1.1.1.42), malate dehydrogenase (Mdh3,4; EC 1.1.1.37), malic enzyme (Me3; EC 1.1.1.40), and superoxide dismutase (Sod1; EC 1.15.1.1). The electrophoretic procedures used follow those described by Utter, Hodgins, and Allendorf (1974) and Allendorf et al. (1977), except that imidazole buffer (Dawson and Mitchell 1969) was used in the staining solution for Idh2 to enhance enzyme activity. Wholefish homogenates were used to screen enzymes from all the loci except Gll and Idh 3,4 , for which eye tissue was used. Only 131 fish were used in analyses in which all heterozygosity classes were compared, as one individual from the third hatching group could not be accurately scored for Idh2 and G3p1.

\section{RESULTS}

HETEROZYGOSITY AND SIZE

There is a significant positive association between heterozygosity and length in Eagle Lake rainbow trout from experiment 1 (fig. $1 ; P<.025)$. These fish were produced by randomly combining the gametes from 25 males and 25 females. There are no significant differences in the lengths of homozygous and heterozygous fish from experiment 1 at any loci except Me3 and Sod1. Heterozygotes are significantly longer than homozygotes at Me3 and Sod1 (table 1). However, the differences at $\mathrm{Me} 3$ and Sod1 are not significant if we take into account that seven independent tests were performed (Cooper 1968). The association between heterozygosity and weight is not significant within any of the six temporal hatching groups examined in experiment 2 (fig. 2). These fish were produced by randomly combining the gametes from 10 males and 10 females.

It is not possible to examine directly the association between heterozygosity and size between fish from the different hatching 


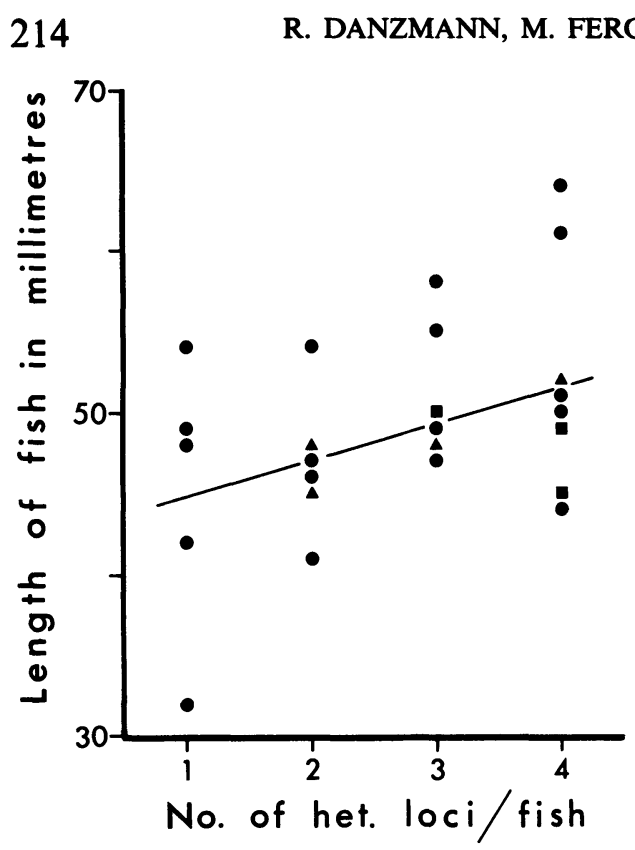

FIG. 1.-Regression of length on number of heterozygous loci per fish in experiment $1(y=42.79+2.19 x$; $P<.025)$. The solid circles, squares, and triangles represent points where one, two, or three fish, respectively, have the same lengths.

groups in experiment 2 because different rearing conditions among the hatching groups (e.g., densities and food rations) potentially confound such comparisons.
However, we could indirectly examine this relationship using a blocked ANOVA design. In this analysis, homozygotes and heterozygotes for each locus are considered the treatments and the hatching groups are considered blocks (Sokal and Rohlf 1981). No significant differences were detected among treatments (heterozygotes vs. homozygotes) at any locus. However, heterozygotes were larger on average than homozygotes for 24 out of 33 possible comparisons within hatching groups $(P$ $=.007$; one-tailed sign test; table 2 ).

In experiment 2 , we also compared the average number of heterozygous loci per fish in each hatching group to the average lengths of 50 additional fish sampled from each of the six hatching groups at the time of yolk-sac absorption. These 300 fish were from the same hatching groups as the fish used in the estimation of $\mathrm{VO}_{2}$ but were sampled prior to the onset of exogenous feeding. These fish all shared a common environment as they were reared in adjacent sections of a single Heath incubating tray, and, therefore, their lengths could be compared directly. The lengths of the fish were measured with Vernier calipers to onetwentieth of a millimeter. A one-way ANOVA with the $T$ method (equal sample

TABLE 1

MEAN LENGTHS (mm) OF HOMOZYGOUS (Hom) AND HETEROZYGOUS (Het) FISH AT SEVEN ENZYME LOCI, REARED IN EXPERIMENT 1

\begin{tabular}{|c|c|c|c|c|}
\hline Locus & $\begin{array}{c}\text { Genotypic } \\
\text { Class }\end{array}$ & $N$ & Mean Length & $P^{\mathrm{a}}$ \\
\hline$G 3 p 1 \ldots$ & $\begin{array}{l}\text { Hom } \\
\text { Het }\end{array}$ & $\begin{array}{l}18 \\
21\end{array}$ & $\begin{array}{l}49.39 \\
47.76\end{array}$ & .321 \\
\hline$G l 1 \ldots \ldots$ & $\begin{array}{l}\text { Hom } \\
\text { Het }\end{array}$ & $\begin{array}{l}30 \\
10\end{array}$ & $\begin{array}{l}48.03 \\
48.40\end{array}$ & .431 \\
\hline $\operatorname{Idh} 2$ & $\begin{array}{l}\text { Hom } \\
\text { Het }\end{array}$ & $\begin{array}{l}27 \\
11\end{array}$ & $\begin{array}{l}47.63 \\
50.27\end{array}$ & .106 \\
\hline $\operatorname{Idh} 3,4 \ldots \ldots$ & $\begin{array}{l}\text { Hom } \\
\text { Het }\end{array}$ & $\begin{array}{r}3 \\
37\end{array}$ & $\begin{array}{l}49.33 \\
48.03\end{array}$ & .359 \\
\hline$M d h 3,4 \ldots$ & $\begin{array}{l}\text { Hom } \\
\text { Het }\end{array}$ & $\begin{array}{r}31 \\
8\end{array}$ & $\begin{array}{l}48.19 \\
48.00\end{array}$ & .467 \\
\hline$M e 3 \ldots \ldots$ & $\begin{array}{l}\text { Hom } \\
\text { Het }\end{array}$ & $\begin{array}{r}31 \\
9\end{array}$ & $\begin{array}{l}47.19 \\
51.33\end{array}$ & .029 \\
\hline Sodl $\ldots$. & $\begin{array}{l}\text { Hom } \\
\text { Het }\end{array}$ & $\begin{array}{l}27 \\
13\end{array}$ & $\begin{array}{l}46.85 \\
50.77\end{array}$ & .022 \\
\hline
\end{tabular}

${ }^{a}$ One-tailed probabilities. 


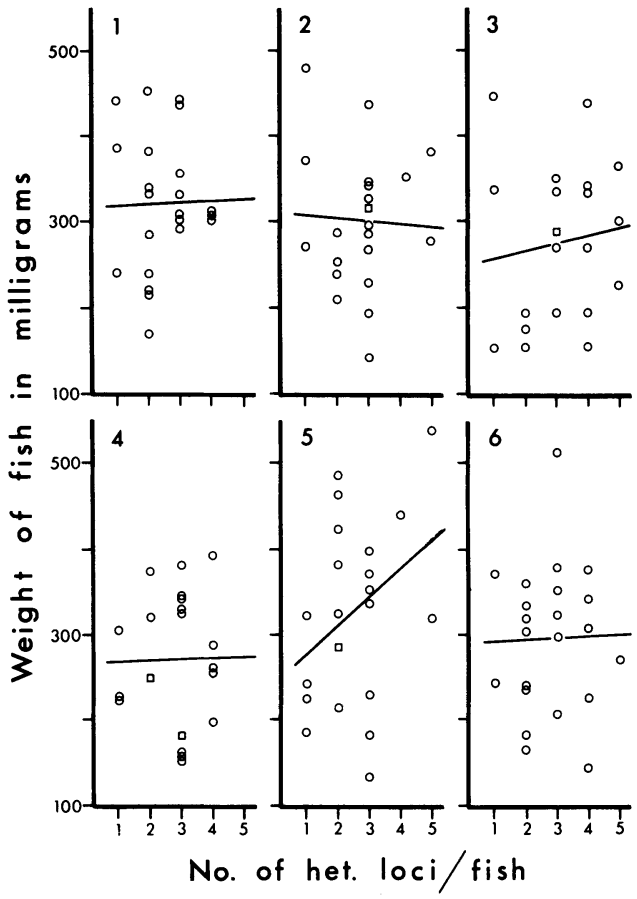

FIG. 2.-Regression of weight on number of heterozygous loci per fish in each hatching group from experiment 2. The numbers in the upper-left corners of each graph represent the hatching groups: $(1 ; y$ $=3.16 .79+1.70 x: 2 ; y=307.92-2.71 x: 3 ; y=248.08$ $+8.72 x: 4 ; y=262.84+1.90 x: 5 ; y=242.60+32.66 x$. $6 ; 289.35+2.03 x)(P>.05$ in all cases). The open squares represent a point where two fish have similar weights.

sizes) of a posteriori means comparison (Sokal and Rohl 1981) was used to test for differences in the mean lengths of fish among the hatching groups and in the average number of heterozygous loci per fish among the different hatching groups. There are no significant differences among hatching groups in the average number of heterozygous loci per fish $\left(F_{[5,125]}=1.13\right)$. However, significant differences in the mean lengths of the fish existed between hatching groups $\left(F_{[5,294]}=6.15 ; P<.001\right)$. As indicated by the $T$ intervals in figure 3 , fish in the tails of the hatching distribution tended to be smaller than those in the middle. For example, fish in the first hatching group are significantly smaller than fish in the second, third, fourth, and fifth hatching groups, while fish in the sixth hatching group are significantly smaller than fish from the third and fourth hatching groups (fig. 3). Hatching groups composed of more heterozygous fish tended to have fish that were larger (Spearman rank correlation coefficient $=0.50 ; N=6 ; P>.05 ;$ fig. 3 ).

\section{HETEROZYGOSITY AND OXYGEN- CONSUMPTION RATE}

There is a significant negative association between $\mathrm{VO}_{2}$ and heterozygosity for all the fish examined in experiment 2 (fig. 4; $P$ $=.04$ ). More heterozygous fish used less oxygen than more homozygous fish. Regression analysis indicated that the strength of the relationship was weak, as the coefficient of determination accounted for only $3 \%$ of the variation. The regression equations relating $\mathrm{VO}_{2}$ and the number of heterozygous loci per fish in each of the six hatching groups indicated more heterozygous fish used less oxygen than more homozygous fish in five out of six hatching groups. However, this relationship was not significant in any group. The equations for the first to the last hatching group, respectively, are $y=115.90-4.63 x ; y=103.56$ $-1.24 x, y=119.34-4.34 x ; y=110.51$ $-1.69 x ; y=117.57-3.78 x ; y=103.59$ $+0.19 x$. No significant differences are present in $\mathrm{VO}_{2}$ between genotypes at any locus except Idh2. Idh2 heterozygotes and (140/140) homozygotes used significantly less oxygen than $(100 / 100)$ homozygotes $\left(F_{[2,128]}=7.09 ; P<.005\right.$; one-way ANOVA).

\section{HETEROZYGOSITY AND HATCHING TIME}

We observed no significant differences in the number of heterozygous loci per fish between hatching groups in experiment 2 . The regression equation relating the hatching group of a fish (dependent variable) to the number of heterozygous loci per fish (independent variable) is $y=3.44+0.02 x$; $F_{[1,126]}=0.05 ; P>.75$. Also, there are no significant differences in the hatching distributions of homozygotes and heterozygotes at any locus (table 3 ). No significant association between hatching time and heterozygosity of all loci combined was observed in a previous analysis of this strain (Danzmann, Ferguson, and Allendorf 1986). Therefore, heterozygosity does not appear to be associated with differences in developmental rate in this strain of rainbow trout. Significant differences in the hatching distributions of genotypic classes at Idh3,4 were, however, evident in the present study. 
Fish with the Idh3,4 (100), (71), and (114) alleles hatched significantly sooner than those with the (40) allele (Wilcoxon twosample test) (table 3 ). The hatching distributions of these genotypes had the same rank order in a previous study using Eagle Lake and other strains of rainbow trout (Danzmann et al. 1986).
OXYGEN-CONSUMPTION RATE AND HATCHING TIME

We found no significant association between $\dot{\mathrm{V}}_{2}$ per fish and hatching group of the fish in experiment 2 (fig. 5). However, since there are no significant differences between the average heterozygosity of fish in the different hatching groups in the present experiment, the lack of an association be-

TABLE 2

THE MEAN WEIGHTS (mg) OF HOMOZYGOTES AND HETEROZYGOTES AT SIX ENZYME LOCI WITHIN EACH OF THE SIX HATCHING GROUPS

\begin{tabular}{|c|c|c|c|c|c|c|}
\hline \multirow{2}{*}{$\begin{array}{l}\text { LOCUS AND } \\
\text { GENOTYPES }\end{array}$} & \multicolumn{6}{|c|}{ HATCHING GROUP } \\
\hline & 1 & 2 & 3 & 4 & 5 & 6 \\
\hline \multicolumn{7}{|l|}{ G3pl } \\
\hline Hom. & $\begin{array}{c}320.36 \\
(13)\end{array}$ & $\begin{array}{c}300.33 \\
(11)\end{array}$ & $\begin{array}{c}279.11 \\
(9)\end{array}$ & $\begin{array}{c}267.41 \\
(13)\end{array}$ & $\begin{array}{c}323.05 \\
(11)\end{array}$ & $\begin{array}{c}289.50 \\
(12)\end{array}$ \\
\hline Het. & $\begin{array}{c}321.83 \\
(9)\end{array}$ & $\begin{array}{c}300.47 \\
(11)\end{array}$ & $\begin{array}{c}272.77 \\
(12)\end{array}$ & $\begin{array}{c}269.14 \\
(9)\end{array}$ & $\begin{array}{c}325.44 \\
(11)\end{array}$ & $\begin{array}{c}301.56 \\
(10)\end{array}$ \\
\hline \multicolumn{7}{|l|}{ Gll } \\
\hline Hom. & $\begin{array}{c}321.98 \\
(15)\end{array}$ & $\begin{array}{c}295.62 \\
(13)\end{array}$ & $\begin{array}{c}233.22 \\
(11)\end{array}$ & $\begin{array}{c}265.03 \\
(11)\end{array}$ & $\begin{array}{c}331.45 \\
(13)\end{array}$ & $\begin{array}{c}294.58 \\
\text { (11) }\end{array}$ \\
\hline Het. & $\begin{array}{c}318.79 \\
(7)\end{array}$ & $\begin{array}{c}307.31 \\
(9)\end{array}$ & $\begin{array}{c}304.04 \\
(11)\end{array}$ & $\begin{array}{c}271.21 \\
(11)\end{array}$ & $\begin{array}{c}313.84 \\
(9)\end{array}$ & $\begin{array}{l}295.38 \\
\text { (11) }\end{array}$ \\
\hline \multicolumn{7}{|l|}{$I d h 2$} \\
\hline Hom. .... & $\begin{array}{c}289.50 \\
(14)\end{array}$ & $\begin{array}{c}301.14 \\
(14)\end{array}$ & $\begin{array}{l}264.27 \\
(12)\end{array}$ & $\begin{array}{c}267.85 \\
(17)\end{array}$ & $\begin{array}{c}297.69 \\
(15)\end{array}$ & $\begin{array}{c}308.32 \\
(14)\end{array}$ \\
\hline Het. & $\begin{array}{c}338.94 \\
(8)\end{array}$ & $\begin{array}{c}299.11 \\
(8)\end{array}$ & $\begin{array}{c}290.44 \\
(9)\end{array}$ & $\begin{array}{c}269.02 \\
(5)\end{array}$ & $\begin{array}{c}381.16 \\
(7)\end{array}$ & $\begin{array}{c}271.64 \\
(8)\end{array}$ \\
\hline \multicolumn{7}{|l|}{$I d h 3,4$} \\
\hline Hom. & $\begin{array}{c}267.30 \\
(5)\end{array}$ & $\begin{array}{l}271.00 \\
\text { (1) }\end{array}$ & $\ldots$ & $\ldots$ & $\cdots$ & $\begin{array}{c}426.85 \\
(2)\end{array}$ \\
\hline Het. & $\begin{array}{c}336.75 \\
(17)\end{array}$ & $\begin{array}{c}301.80 \\
(21)\end{array}$ & & & & $\begin{array}{c}281.80 \\
20)\end{array}$ \\
\hline$(40)^{a}$ & $\cdots$ & $\begin{array}{c}285.48 \\
(4)\end{array}$ & $\begin{array}{c}223.42 \\
(6)\end{array}$ & $\begin{array}{c}251.35 \\
(11)\end{array}$ & $\begin{array}{c}283.50 \\
(4)\end{array}$ & $\begin{array}{c}289.60 \\
(10)\end{array}$ \\
\hline (71) & $\begin{array}{c}329.54 \\
(16)\end{array}$ & $\begin{array}{c}306.27 \\
(19)\end{array}$ & $\begin{array}{c}270.53 \\
(20)\end{array}$ & $\begin{array}{c}268.60 \\
(19)\end{array}$ & $\begin{array}{c}330.72 \\
(21)\end{array}$ & $\begin{array}{c}274.46 \\
(16)\end{array}$ \\
\hline (114) & $\begin{array}{c}365.80 \\
(3)\end{array}$ & $\begin{array}{c}259.18 \\
(5)\end{array}$ & $\begin{array}{c}274.33 \\
(3)\end{array}$ & $\begin{array}{l}343.70 \\
(1)\end{array}$ & $\begin{array}{c}533.70 \\
(1)\end{array}$ & $\begin{array}{c}350.80 \\
(1)\end{array}$ \\
\hline \multicolumn{7}{|l|}{$M d h 3,4$} \\
\hline Hom. & $\begin{array}{c}329.11 \\
(15)\end{array}$ & $\begin{array}{c}292.78 \\
(17)\end{array}$ & $\begin{array}{c}262.98 \\
(16)\end{array}$ & $\begin{array}{c}269.00 \\
(15)\end{array}$ & $\begin{array}{c}316.68 \\
(19)\end{array}$ & $\begin{array}{c}288.87 \\
(18)\end{array}$ \\
\hline Het. & $\begin{array}{c}303.50 \\
(7)\end{array}$ & $\begin{array}{c}326.30 \\
(5)\end{array}$ & $\begin{array}{c}283.70 \\
(6)\end{array}$ & $\begin{array}{c}266.23 \\
(7)\end{array}$ & $\begin{array}{c}372.13 \\
(3)\end{array}$ & $\begin{array}{c}322.48 \\
(4)\end{array}$ \\
\hline \multicolumn{7}{|l|}{ Sodl } \\
\hline Hom. .... & $\begin{array}{c}312.04 \\
(16)\end{array}$ & $\begin{array}{l}287.76 \\
(14)\end{array}$ & $\begin{array}{c}288.44 \\
(14)\end{array}$ & $\begin{array}{c}267.90 \\
(15)\end{array}$ & $\begin{array}{c}304.59 \\
(18)\end{array}$ & $\begin{array}{c}272.21 \\
(14)\end{array}$ \\
\hline Het. & $\begin{array}{c}344.75 \\
(6)\end{array}$ & $\begin{array}{c}307.62 \\
(8)\end{array}$ & $\begin{array}{c}233.96 \\
(8)\end{array}$ & $\begin{array}{c}268.59 \\
(7)\end{array}$ & $\begin{array}{c}412.68 \\
(4)\end{array}$ & $\begin{array}{c}334.84 \\
(8)\end{array}$ \\
\hline
\end{tabular}

NOTE.-Numbers in parentheses indicate the sample sizes.

Any individual possessing the Idh3,4 allele indicated is included in the estimation of average weights for that genotype class. Since individuals can be heterozygous for more than one allele they may be included in more than one genotypic class. 


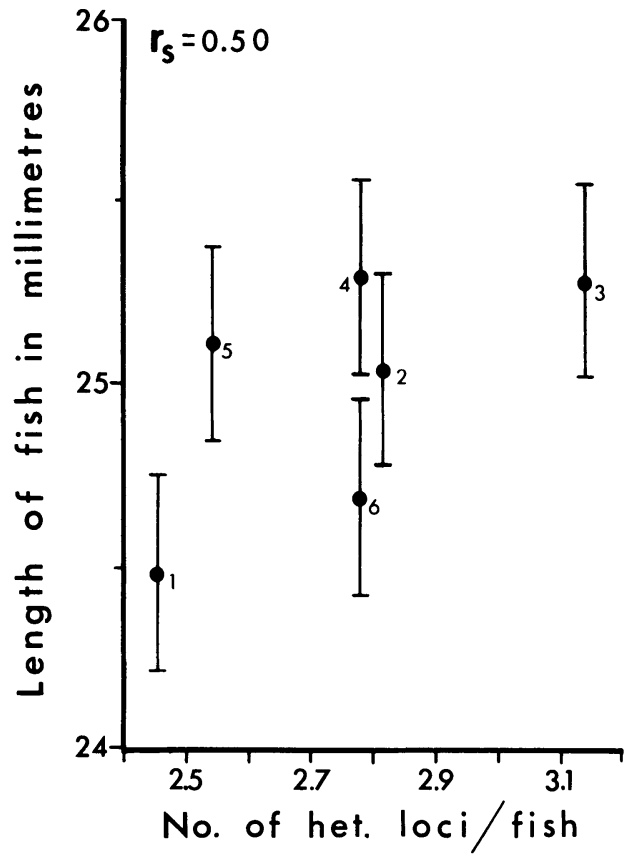

FIG. 3.-Spearman rank correlation between the average lengths of 50 fish from each of the six hatching groups and the average number of heterozygous loci from 22 additional fish from each of the hatching groups. The hatching groups are designated beside the means for these two variables. No significant differences in the average number of heterozygous loci per fish were evident between hatching groups. However, significant differences in the average lengths of fish were detected between hatching groups. The $T$ intervals (one-way ANOVA) around the mean length estimates are indicated on the figure.

tween respiration rate and hatching time is expected. Similarly, there are no significant differences in $\mathrm{VO}_{2}$ between fish in different hatching groups $\left(F_{[5,125]}=0.64\right)$.

We next compared the hatching distributions and $\mathrm{VO}_{2}$ of homozygotes and heterozygotes at each locus. Fish in the genotypic class using less oxygen hatched sooner for five out of the six loci compared (table $3)$. For example, at $G 3 p 1$ and $G l 1$, heterozygotes used more oxygen and hatched later than homozygotes, while, at Idh2, Mdh3,4, and Sod1, heterozygotes used less oxygen and hatched sooner than homozygotes. The same relationship between $\dot{\mathrm{VO}}_{2}$ and hatching time was also evident for the three heterozygous genotypes at Idh3,4.Idh3,4 (114) genotypes hatched sooner than (71) genotypes, which, in turn, hatched sooner than (40) genotypes. Idh3,4 (114) genotypes also used less oxygen than (71) genotypes, which, in turn, used less oxygen than (40) genotypes. Idh3,4 homozygotes, however, hatched earlier than heterozygotes but also used more oxygen.

\section{DISCUSSION}

The results from this study support those of previous investigations which suggest that heterozygotes are metabolically more efficient than homozygotes (Koehn and Shumway 1982; Garton 1984; Garton et al. 1984; Diehl et al. 1985a). More heterozygous Eagle Lake rainbow trout use less oxygen than homozygotes. This appears to be associated with a positive scope for growth as more heterozygous fish are also larger (figs. 1, 2).

Our findings also suggest that faster developmental rates may in part result from increased metabolic efficiency. Fish within the genotypic class (heterozygous or homozygous) using less oxygen hatched sooner at five out of the six loci examined. This evidence is only indirect, however, and

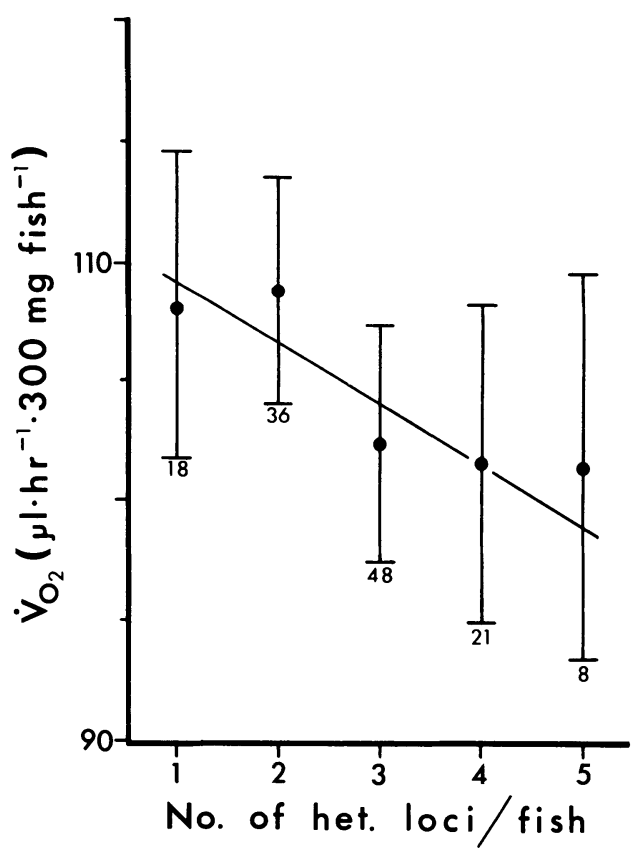

FIG. 4.-Regression of mean oxygen-consumption rates on multilocus heterozygosity classes in experiment $2(y=111.70-2.57 x, P<.05)$. Vertical bars represent twice the standard error of the mean estimate. The numbers below the bars represent the number of fish sampled in each heterozygosity class. 
assumes that the rank order of oxygen-consumption rates among genotypes remains the same throughout development.

Even though heterozygous fish reared in experiment 2 tended to be larger than homozygous fish, the differences in size associated with heterozygosity were not significant within any hatching group in experiment 2 . There are two reasons why an association between heterozygosity and size may not be readily detectable within hatching groups. If differences in developmental rates directly influence the size of fish, we would then expect less size variation within than between hatching groups. It is not possible to directly compare between hatching groups because these fish were reared in separate environments after yolk-

TABLE 3

MEAN RESPIRATION RATES $\left(\dot{\mathrm{V}}_{2}=\mu \mathrm{l} \cdot \mathrm{hr}^{-1} \cdot 300 \mathrm{mg} \mathrm{fish}^{-1}\right)$ AND HATCHING GROUP (H.G.) OF FISH WITH DIFFERENT GENOTYPES AT SIX ENZYME LOCI

\begin{tabular}{|c|c|c|c|c|}
\hline Locus & Genotype & $\mathrm{N}$ & Mean $\dot{\mathrm{VO}}_{2}$ & Mean H.G. \\
\hline G3pl & $\begin{array}{c}100 / 100 \\
100 / 140 \\
140 / 140 \\
(\text { Hom })^{\mathrm{a}}\end{array}$ & $\begin{array}{l}53 \\
62 \\
16 \\
69\end{array}$ & $\begin{array}{l}104.81 \\
105.30 \\
101.89 \\
104.13\end{array}$ & $\begin{array}{l}3.62 \\
3.52 \\
3.06 \\
3.49\end{array}$ \\
\hline Gll $\ldots \ldots$ & $\begin{array}{c}100 / 100 \\
100 / 120 \\
120 / 120 \\
\text { (Hom) }\end{array}$ & $\begin{array}{r}66 \\
58 \\
8 \\
74\end{array}$ & $\begin{array}{l}103.35 \\
105.95 \\
107.15 \\
103.76\end{array}$ & $\begin{array}{l}3.33 \\
3.67 \\
3.63 \\
3.36\end{array}$ \\
\hline Idh2 & $\begin{array}{c}100 / 100 \\
100 / 140 \\
140 / 140 \\
\text { (Hom) } \\
\text { Sig. }\end{array}$ & $\begin{array}{l}66 \\
45 \\
20 \\
86\end{array}$ & $\begin{aligned} 109.51 \\
99.35 \\
100.77 \\
107.47 \\
1 \gg 2,3 \\
\text { Het } \ll \text { Hom }\end{aligned}$ & $\begin{array}{l}3.71 \\
3.42 \\
3.00 \\
3.55\end{array}$ \\
\hline $\operatorname{Idh} 3,4^{c} \ldots$ & $\begin{array}{c}100 / 100 \\
100 / 40 \\
40 / 40 \\
71 / 40 \\
100 / 71 \\
71 / 71 \\
114 / 71 \\
114 / 100 \\
114 / 114 \\
(40) \\
(71) \\
(114) \\
\text { (Het) } \\
\text { Sig. }\end{array}$ & $\begin{array}{r}8 \\
5 \\
3 \\
28 \\
40 \\
34 \\
9 \\
4 \\
1 \\
36 \\
111 \\
14 \\
124\end{array}$ & $\begin{array}{r}107.32 \\
104.36 \\
100.10 \\
106.12 \\
103.04 \\
108.50 \\
98.47 \\
95.43 \\
92.96 \\
105.38 \\
105.12 \\
97.21 \\
104.56\end{array}$ & $\begin{array}{c}2.38 \\
4.60 \\
5.00 \\
4.04 \\
2.80 \\
4.21 \\
2.56 \\
3.25 \\
1.00 \\
4.19 \\
3.52 \\
2.64 \\
3.57 \\
100,71<40 \\
114 \ll 40\end{array}$ \\
\hline$M d h 3,4^{c} \ldots$ & $\begin{array}{l}100 / 100 \\
100 / 83\end{array}$ & $\begin{array}{r}100 \\
32\end{array}$ & $\begin{array}{l}105.80 \\
101.36\end{array}$ & $\begin{array}{l}3.60 \\
3.19\end{array}$ \\
\hline Sodl ...... & $\begin{array}{c}100 / 100 \\
100 / 152 \\
152 / 152 \\
\text { (Hom) }\end{array}$ & $\begin{array}{r}86 \\
41 \\
5 \\
91\end{array}$ & $\begin{array}{l}106.07 \\
102.02 \\
103.24 \\
105.92\end{array}$ & $\begin{array}{l}3.50 \\
3.46 \\
3.80 \\
3.52\end{array}$ \\
\hline
\end{tabular}

${ }^{2}$ Mean of combined homozygous (Hom) or heterozygous (Het) genotypes.

b Indicates which genotypes are significantly different at the 0.01 level by having lower $(\ll)$ or higher $(\gg)$ respiration rates or hatching times. $(<)=P<.05$. All other comparisons are not significant.

${ }^{c}$ All fish possess two copies of the (100) allele at these duplicated loci in addition to the allelic variants indicated. 


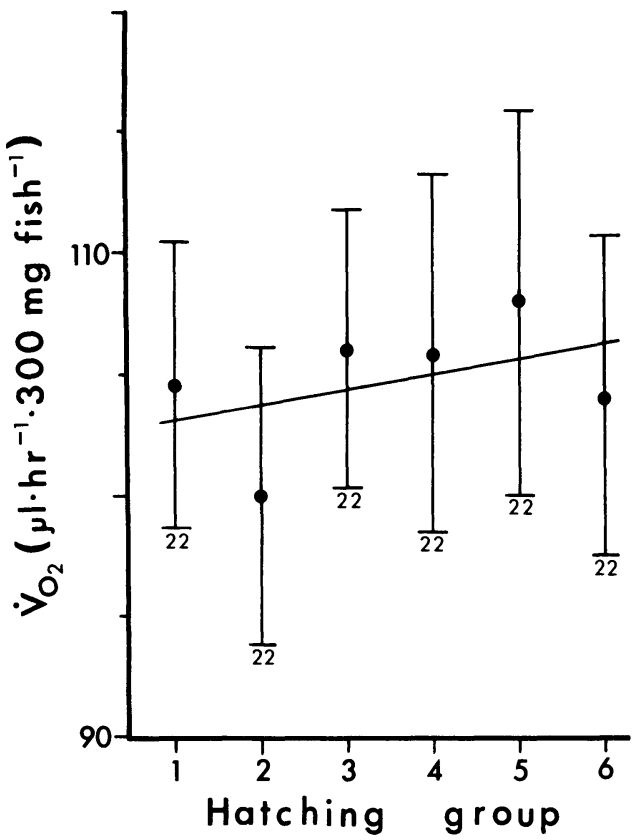

FIG. 5.-Regression of mean oxygen-consumption rates on the hatching group of each fish in experiment $2(y=102.59+0.61 x, P>.05)$. Vertical bars represent twice the standard error of the mean estimate: 22 fish were sampled in each hatching group.

sac resorption. In addition, Beacham, Withler, and Morley (1985) found in chum salmon (Oncorhynchus keta) and coho salmon ( $O$. kisutch) that body size of hatched embryos and embryos at yolk-sac resorption was directly related to egg size. Therefore, if large or small eggs all tended to hatch toward one end or in the middle of the hatching distribution, there would be reduced size variation within hatching groups. Consequently, most of the size variation is expected between fish from different hatching groups. Beacham et al. (1985) did not detect any differences in hatching time between different-sized embryos. However, it is premature to conclude that egg size has no influence on development time, as their analysis was based only on three females from each species. Future experiments will examine the relationship among heterozygosity, $\dot{\mathrm{VO}}_{2}$, and body size in the same pooled group of embryos, and developmental rates of fish with different genotypes will be inferred from a subset of this pool sampled at hatching time.

The present data do not allow us to attribute decreased oxygen consumption to the direct action of heterozygosity at the enzyme loci. There are two other explanations that may also account for the observed relationship between $\dot{\mathrm{VO}}_{2}$ and heterozygosity: inbreeding and linkage disequilibrium. Under the first hypothesis, more homozygous fish are presumed to be more inbred and therefore more likely to express deleterious genes thai might decrease metabolic efficiency. This is an unlikely explanation, however, since the fish were produced by randomly mating 10 males and 10 females. Therefore, homozygotes should not be more inbred than heterozygotes.

Alternatively, these loci may be marking chromosomal segments that carry other genes influencing metabolic rate. In a study examining the association between heterozygosity and hatching time in six strains of rainbow trout, Danzmann et al. (1986) have shown that the enzyme loci examined appear to be markers of other genes affecting developmental rate. In some strains, heterozygotes at a specific locus hatched significantly sooner than homozygotes, while, in other strains, the opposite was true. A similar approach examining the association between $\mathrm{VO}_{2}$ and heterozygosity in different strains would address this question. A consistent association between heterozygosity and $\mathrm{VO}_{2}$ between strains would suggest that the effects were directly attributable to the locus. Conversely, significant positive associations in some strains-but negative associations in other strains-suggest the loci are marking other genes that influence metabolic rate. Therefore, studies examining this relationship in additional strains are required.

\section{LITERATURE CITED}

ALDERDICE, D. F., W. P. WICKETT, and J. R. BRETT. 1958. Some effects of temporary exposure to low dissolved oxygen levels on Pacific salmon eggs. $J$. Fisheries Res. Board Can. 15:229-249.

ALLENDORF, F. W., N. MITCHELL, N. RYMAN, and G. STÅHL. 1977. Isozyme loci in brown trout
(Salmo trutta L.): detection and interpretation from population data. Hereditas 86:179-190.

ALLENDORF, F. W., and S. R. PHELPS. 1981. Isozymes and the preservation of genetic variation in salmonid fishes. Ecology Bull. 34:37-52.

BEACHAM, T. D., F. C. WITHLER, and R. B. MORLEY. 
1985. Effect of egg size on incubation time and alevin and fry size in chum salmon (Oncorhynchus keta) and coho salmon (Oncorhynchus kisutch). Can. J. Zool. 63:847-850.

Beaumont, A. R., C. M. Beveridge, and M. D. BUDD. 1983. Selection and heterozygosity within single families of the mussel Mytilus edulis (L.). Mar. Biol. Lett. 4:151-161.

COOPER, D. W. 1968. The significance level in multiple tests made simultaneously. Heredity (Edinburgh) 23:614-617.

DANZMANN, R. G., M. M. Ferguson, and F. W. ALLENDORF. 1986. Does enzyme heterozygosity influence developmental rate in rainbow trout? Heredity (Edinburgh) 56:417-425.

DAwson, D. M., and R. Mitchell. 1969. The isoenzymes of phosphoglucomutase. Biochemistry 8 : 609-614.

DiEHL, W. J., P. M. GAFFNEY, and R. K. KOEHN. $1985 a$. Differences in weight standardized oxygen consumption, growth and weight loss between low and high growth Mytilus edulis (Mollusca). Physiologist 28:366.

DiEHL, W. J., P. M. GAFFNEY, J. H. MCDONALD, and R. K. KOHEN. 1985b. Relationship between weightstandardized oxygen consumption and multiplelocus heterozygosity in the marine mussel Mytilus edulis L. (Mollusca). Pages 531-536 in P. GIBBS, ed. Proc. 19th Eur. Mar. Biol. Symp., Cambridge University Press.

FERguSON, M. M., R. G. DANZMANN, and F. W. ALLENDORF. 1985. Developmental divergence among hatchery strains of rainbow trout (Salmo gairdneri). I. Pure strains. Can. J. Genet. Cytol. 27:289-307.

FujIO, Y. 1982. A correlation of heterozygosity with growth rate in the Pacific oyster, Crassostrea gigas. Tohoku J. Agric. Res. 33:66-75.

GARSIDE, E. T. 1966. Effects of oxygen in relation to temperature on the development of embryos of brook trout and rainbow trout. J. Fisheries Res. Board Can. 23:1121-1134.

GARTON, D. W. 1984. The relationship between multiple-locus heterozygosity and the physiological energetics of growth in the estuarine gastropod Thais haemastoma. Physiol. Zool. 57:530-543.

Garton, D. W., R. K. Koehn, and T. M. SCOTt. 1984. Multiple-locus heterozygosity and the physiological energetics of growth in the coot clam $\mathrm{Mu}$ - linia lateralis from a natural population. Genetics 108:445-455.

KING, D. P. F. 1985. Enzyme heterozygosity associated with anatomical character variance and growth in the herring (Clupea harengus L.). Heredity (Edinburgh) 54:289-296.

KOEHN, R. K., and P. M. GAFFNEY. 1984. Genetic heterozygosity and growth rate in Mytilus edulis. Mar. Biol. 82:1-7.

KOEHN, R. K., and S. R. SHUMWAY. 1982. A genetic/ physiological explanation for differential growth rate among individuals of the American oyster Crassostrea virginica (Gmelin). Mar. Biol. Lett. 3: 35-42.

MANWEll, C., and M. A. BAKER. 1982. Alcohol dehydrogenase in the marine polychaete Hyalinoecia tubicola: heterozygote deficit and growth. Comp. Biochem. Physiol. 73B:411-416.

Mitton, J. B., C. CAREY, and T. D. Kocher. 1986. The relation of enzyme heterozygosity to standard and active oxygen consumption and growth rate of the tiger salamander Ambystoma tigrinum. Physiol. Zool. 59:574-582.

RAO, G. M. M. 1968. Oxygen consumption of rainbow trout (Salmo gairdneri) in relation to activity and salinity. Can. J. Zool. 46:781-786.

RoDhouSE, P. G., and P. M. GAFFNEY. 1984. Effect of heterozygosity on metabolism during starvation in the American oyster Crassostrea virginica. Mar. Biol. 80:179-187.

SINGH, S. M. 1982. Enzyme heterozygosity associated with growth at different developmental stages in oysters. Can. J. Genet. Cytol. 24:451-458.

SINGH, S. M., and E. ZouROS. 1978. Genetic variation associated with growth rate in the American oyster (Crassostrea virginica). Evolution 32:342-352.

SOKAL, R. R., and F. J. ROHLF. 1981. Biometry. 2d ed. W. H. Freeman, San Francisco.

UTTER, F. M., H. O. HODGINS, and F. W. ALLENDORF. 1974. Biochemical genetic studies of fishes: potentialities and limitations. Pages 213-238 in D. C. MALINS and J. R. SARGENT, eds. Biochemical and biophysical perspectives in marine biology. Vol. 1. Academic Press, New York.

Zouros, E., S. M. SingH, and H. E. Miles. 1980. Growth rate in oysters: an overdominant phenotype and its possible explanations. Evolution 34:856867. 